Portland State University

PDXScholar

\title{
The Effect of Extended Instruction on Passive Voice, Reduced Relative Clauses, and Modal Would in the Academic Writing of Advanced English Language Learners
}

Audrey Bailey

Portland State University

Follow this and additional works at: https://pdxscholar.library.pdx.edu/open_access_etds

Part of the Applied Linguistics Commons, First and Second Language Acquisition Commons, and the Rhetoric and Composition Commons

Let us know how access to this document benefits you.

\section{Recommended Citation}

Bailey, Audrey, "The Effect of Extended Instruction on Passive Voice, Reduced Relative Clauses, and Modal Would in the Academic Writing of Advanced English Language Learners" (2016). Dissertations and Theses. Paper 3203.

https://doi.org/10.15760/etd.3194

This Thesis is brought to you for free and open access. It has been accepted for inclusion in Dissertations and Theses by an authorized administrator of PDXScholar. Please contact us if we can make this document more accessible: pdxscholar@pdx.edu. 
The Effect of Extended Instruction on Passive Voice, Reduced Relative Clauses, and Modal Would in the Academic Writing of Advanced English Language Learners

\author{
by \\ Audrey Bailey
}

A thesis submitted in partial fulfillment of the requirements for the degree of

\author{
Master of Arts \\ in \\ Teaching English to Speakers of Other Languages
}

Thesis Committee:

Alissa Hartig, Chair

Susan Conrad

Linnea Spitzer

Portland State University 2016 


\begin{abstract}
As more international students who are not expert users of English come to the United States to study at university, the field of teaching English for Academic Purposes grows. There are many important skills these international students must learn to become successful university students in America, but writing for academic purposes is of particular importance for these students to join the academic conversation in their respective disciplines. Corpus research has identified the grammatical features which are frequently found in different registers, and from this work it is known which structures are important in different types of academic writing. Grammatical structures frequently found in the academic register must be taught to these university-bound students. However, many English Language Learners (ELLs) are infrequently using, or inaccurately using, some of these grammatical features in their writing when compared to L1 writers. This study focuses on three of those under-used, and/or inaccurately used structures: passive voice, reduced relative clauses, and modal would.
\end{abstract}

At an Intensive English Language Program (IELP) in the Pacific Northwest, an experimental group of advanced ELLs were given extended instruction-extra time and practice-on these three features. The control group received the standard amount of time and practice students typically receive at this IELP. 25 essays from the experimental group and 44 essays from the control group were tagged for presence, accuracy, and appropriacy of the three grammatical features (passive 
voice, reduced relative clauses, and modal would). The experimental and control group essays were compared to see if the treatment instruction had a significant effect on the frequency, accuracy, and/or appropriacy of these features.

Results from an independent t-test on the frequency of passive voice showed no significant difference between the experimental group essays and the control group essays. Results from a Mann-Whitney U test on the frequency of reduced relative clauses and modal would showed no significant difference between the two groups. In regard to accuracy and appropriacy, a Mann-Whitney U test found no significant difference between the experiment group and control group.

The analysis of the two groups showed that students in the treatment group did use passive voice on average more than students in the control group, but it was not enough to be significantly different. The frequency of reduced relative clauses and modal would was low, yet accuracy and appropriacy of these features was very high for both groups.

These findings reveal that different, or perhaps more focused, approaches must be taken beyond extra time and practice to increase ELLs' use of passive voice, reduced relative clauses, and modal would in their writing. 


\section{Acknowledgements}

There are many who deserve recognition here for their contributions to this work. I am grateful for the connections I made in the TESOL program and at the PSU IELP. I continue to be professionally and personally inspired by you all. Many at this university challenged me to think more deeply about myself as a student, teacher, and professional-and for that I am grateful. I must also acknowledge my family and friends who took care of me during this difficult year, for they are the reason I was able keep moving forward.

To my advisor Alissa Hartig, I have immense gratitude for you. Your thoughtful comments, encouragement, generosity, and patience are the reason this goal was attainable, and you have taught me much about teaching and mentoring. I am also incredibly thankful to my committee members, Susan Conrad and Linnea Spitzer for sharing so much of their time, insight, and experience.

To Linda and Bill, I will always be in awe of the sacrifices you have made for me. Your encouragement and unconditional love continue to propel forward. Thank you for always giving me room to grow.

To my dear friends and colleagues, I am thankful for the thoughtful discussions we had in and outside of class and work. Your dedication to the field, and your willingness to actively listen (to other teachers, the community, and especially to your students) have taught me much. I am especially grateful to Alisa for giving me much needed encouragement and to Josh for his unwavering support and love. 


\section{Table of Contents}

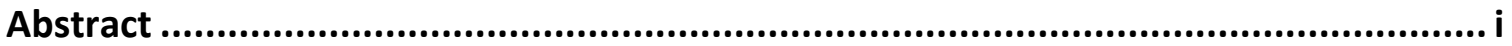

Acknowledgements ...................................................................................... iii

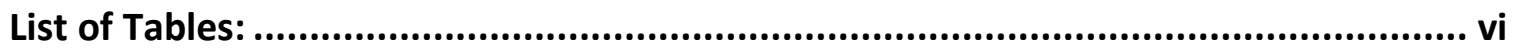

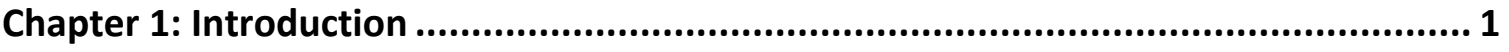

Chapter 2: Review of Literature .................................................................... 3

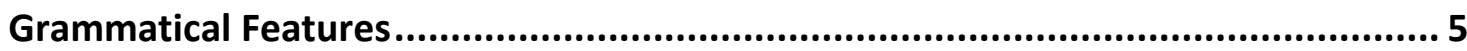

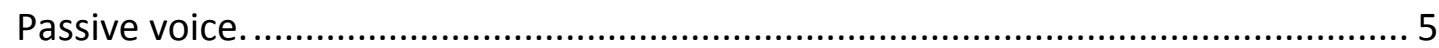

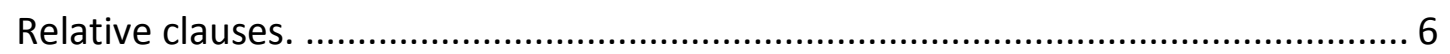

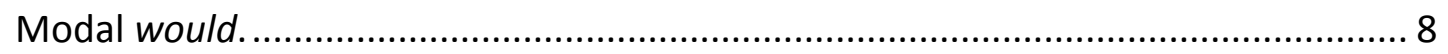

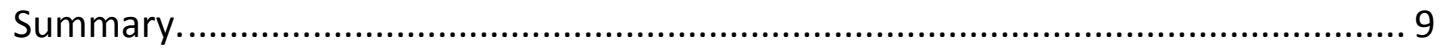

Teaching Grammar for Academic Writing .................................................. 9

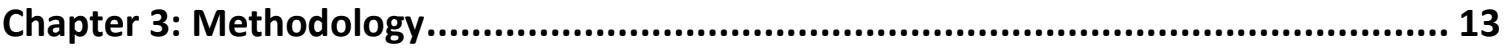

Context of Study ............................................................................... 13

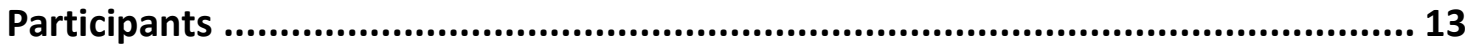

Materials and Instruments ......................................................................... 14

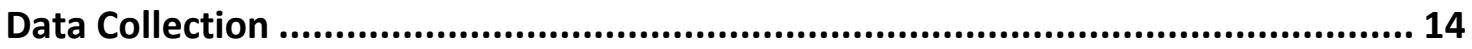

Treatment Instruction ........................................................................... 15

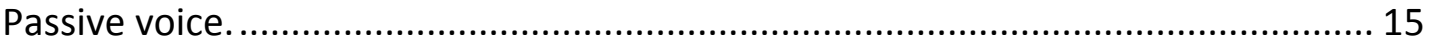

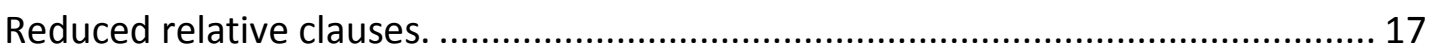

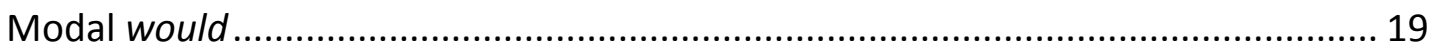

Analysis Procedures .......................................................................... 20

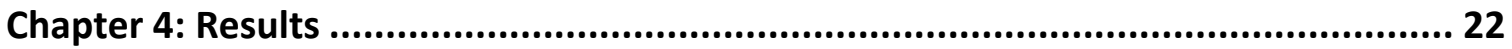

Data Coding Procedures ....................................................................... 22

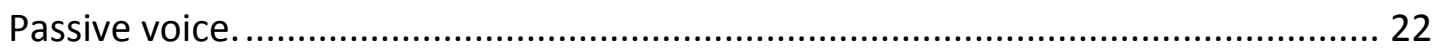

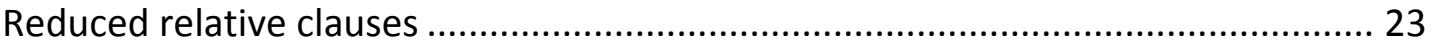

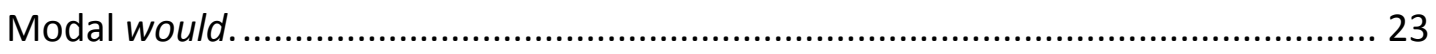

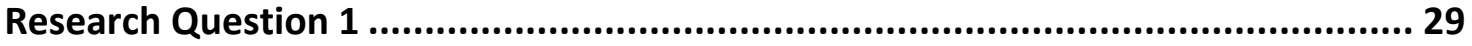

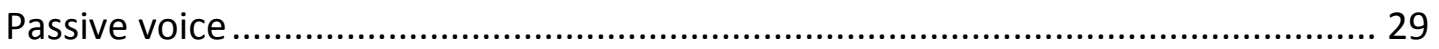

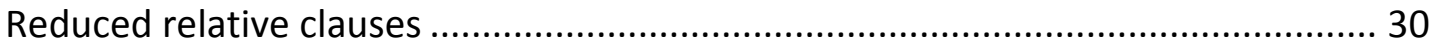

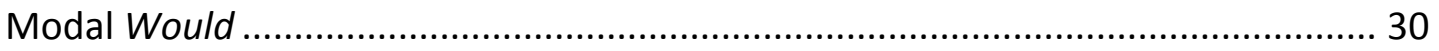

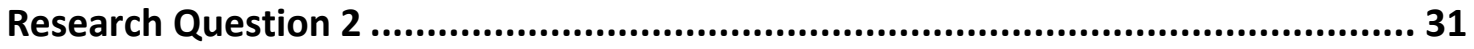

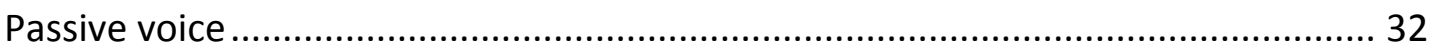

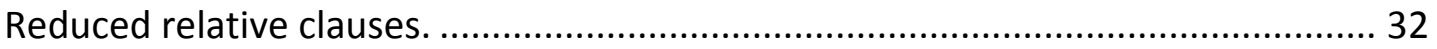

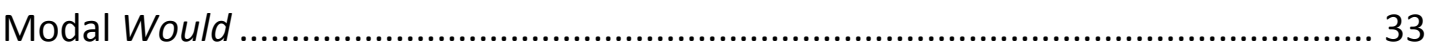

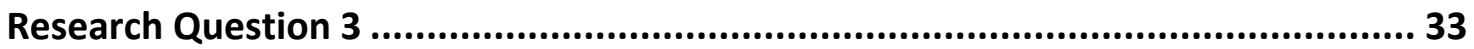




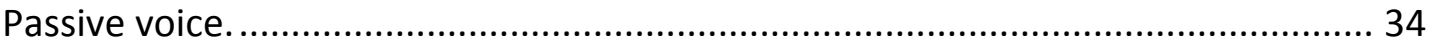

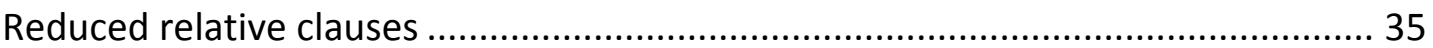

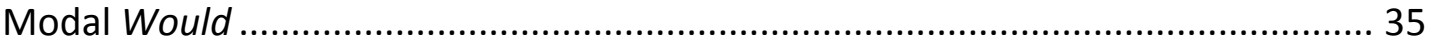

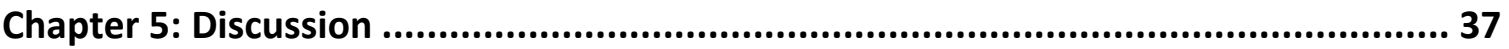

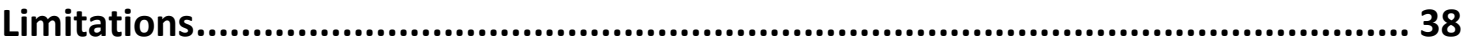

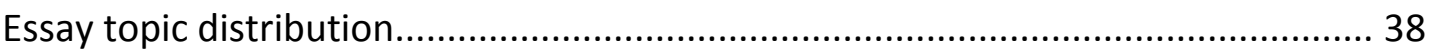

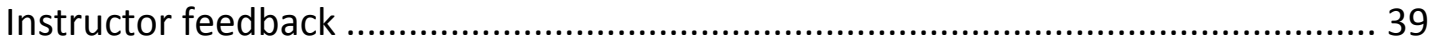

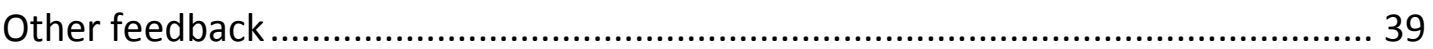

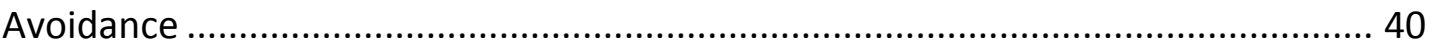

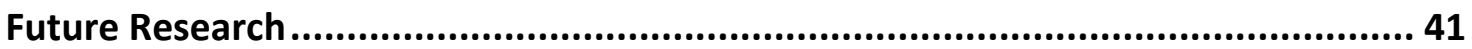

Reduced relative clauses and modal would ......................................................... 41

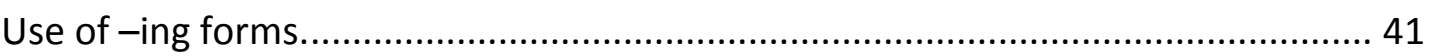

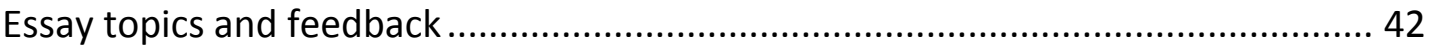

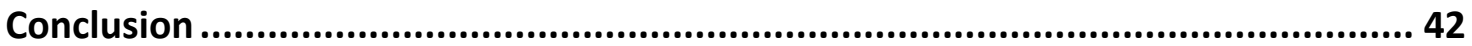

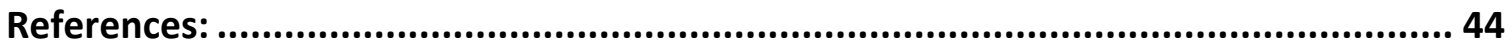




\section{List of Tables:}

Table 2.1: Full and reduced relative clauses

Table 3.1: Essay topic distribution 14

Table 3.2: Description of passive voice control and treatment instruction 15

Table 3.3: Description of reduced relative clause control and treatment instruction 17

Table 3.4: Description of modal would control and treatment instruction 19

Table 4.1: Passive voice data coding procedures 25

Table 4.2: Reduced relative clauses data coding procedures 26

Table 4.3: Modal would data coding procedures 28

Table 4.4: Frequency of features in treatment and control groups 29

Table 4.5: Frequency statistics for passive voice 30

Table 4.6: Frequency statistics for reduced relative clauses 30

Table 4.7: Frequency statistics for modal would 31

Table 4.8: Accuracy of features in treatment and control groups 31

Table 4.9: Accuracy statistics for passive voice 32

Table 4.10: Accuracy statistics for reduced relative clauses 33

Table 4.11: Accuracy statistics for modal would 33

Table 4.12: Appropriacy of features in treatment and control groups 34

Table 4.13: Appropriacy statistics for passive voice 35

Table 4.14: Appropriacy statistics for reduced relative clause 35

Table 4.15: Accuracy statistics for modal would 36 


\section{Chapter 1: Introduction}

English for Academic Purposes is a field which continues to expand as increasingly more English Language Learners (ELLs) are bound for American universities. Many Intensive English Language Programs in America work to prepare students who have academic goals. The content of that curriculum is often informed by research which has identified skills these ELLs will need to succeed. In addition to listening, speaking, and reading, students must learn to form grammatically correct written sentences that are academic in tone. From corpus research, we know which grammatical structures are frequently found in academic writing; however, these structures may be difficult for ELLs to form correctly or use appropriately in their academic writing (Hinkel, 2002b; 2004). ELLs may even avoid using these structures for fear of forming or using them incorrectly. From prior research, it is clear that the academic writing from ELLs and L1 students in university differ in regard to frequency of certain grammatical features. Further, ELLs are often more likely to use grammatical structures associated with conversation in their academic writing (Hinkel, 2002b).

An important next step for those in the field of English for Academic purposes is to increase ELLs' frequency, accuracy, and appropriacy of important grammatical features in their academic writing. While researchers have not found the single best way to teach grammar, much is known about effective ways to teach these difficult structures, and using multiple methods-rather than relying on one- 
can lead to results. Research shows that extended time learning about, identifying, practicing, and producing grammatical features can have a positive impact on acquisition of that feature (Balcom \& Lee, 2009; Norris \& Ortega, 2002; Nassaji \& Fotos, 2004)

This study examines the effect of extended instruction of three grammatical structures: passive voice, reduced relative clauses, and modal would. These structures were chosen for two reasons: they are frequently used in academic writing of L1 students (Biber, Conrad, \& Leech, 2002)—but are infrequently used, formed incorrectly, and/or used inappropriately by ELLs in academic writing (Hinkel, 2002b) — and they were identified as markedly different in a study examining the differences between ELLs and L1 students at a public university in the Pacific Northwest (Russell, 2014). An experiment was designed to see if extended instruction on passive voice, reduced relative clauses, and modal would has an effect on ELLs' frequency, accuracy, and use of these features. The treatment group received extended instruction (extra time and practice) on those three features. The control group received traditional grammar instruction, as described in Russell (2014)'s study. The data analyzed were written academic essays, which students composed as a final assignment the same term they were enrolled in either the treatment or control group grammar class. 


\section{Chapter 2: Review of Literature}

Each year, American universities accept increasingly more international students, many of whom do not have English as their first language (Institute of International Education, 2015). Among other important skills required for these English Language Learners (ELLs) to succeed at an American university, the task of producing academic writing is one many find challenging. Students must attend to rhetorical expectations, register, vocabulary, and grammatical accuracy. Many scholars have looked at student writing from English as a first language (L1) students to better understand what makes "good" writing in the university setting (Jordan, 2009; Swales \& Feak, 2012; Hinkel, 2004). If scholars can identify the components of "good" writing, English for Academic Purposes instructors can adjust curriculum, which may lead to better outcomes for ELLs composing for academic purposes. Some studies focus on the stylistic variation typical of highly-rated essays (Fringel, Li, \& Weigle, 2014); others look to the distribution of lexical and grammatical features (Jarvis, Grant, Bibowski, \& Grant, 2003; Hinkel 2002b). However, a complete picture of "good" writing has not emerged.

Thanks to corpus linguistics, scholars have clearly identified certain grammatical structures that are frequently found in expert writing. Often, these structures differ from conversational registers. Unfortunately, studies have found that ELLs frequently use grammatical structures in their academic writing which are more common in conversation, such as progressive aspect (Biber, Conrad, \& Leech, 2002). These structures may be more familiar to students who have studied 
speaking and listening more often than writing, or the structures may be perhaps easier to master. One corpus-based study done by Hinkel (2002b) focused on grammatical features to determine how ELL and L1 papers differ in that regard. She examined features that fall under the three categories of syntactic and lexical, clausal, and rhetorical. A primary conclusion was that many ELLs were in fact using grammatical structures in their academic writing which were more common to conversation, such as cause and condition clauses. Structures not often found in conversation such as passive voice, reduced relative clauses, and modal would were infrequently used by ELLs. Hinkel's (2002b) analysis of the differences between L1 and ELL academic writing identified important issues which help inform further research.

Russell (2014) used Hinkel's (2002b) study of 68 linguistic and rhetorical features as the impetus to look at academic writing from a specific setting. Russell analyzed the academic writing ELLs from Portland State University's Intensive English Language Program had produced and compared it to the academic writing produced by multi-disciplinary Portland State University Students whose L1 was English. Russell chose 13 features Hinkel had identified as differing significantly in ELL and L1 writing, selecting features which represent different parts of speech and semantic use. After her data collection, she chose the features which showed the more pronounced difference. Russell investigated the usage of these features by each group. The usage of these features by ELLs was more conversational, matching Hinkel's (2002b) findings. There were five structures with pronounced differences: 
modal would, passive voice, perfect aspect, reduced relative clauses, and it-clefting. When these features were used in ELL writing, it was often ungrammatical. Russell also found that ELLs infrequently used reduced relative clauses and often chose to use full relative clauses instead. While both of these features are frequently used in academic writing, the ELLs did not demonstrate mastery of usage for form or appropriacy. Russell speculated that more focused instruction on these features could lead to more successful outcomes, and she designed several in-class assignments for these features.

\section{Grammatical Features}

From Russell's findings and work, an experiment was designed to implement extended instruction of passive voice, reduced relative clauses, and modal would in two sections of grammar classes in the same context Russell studied. The extended instruction included more class time allotted to these three features, and additional practice and assignments. In describing these three features, and how the extended instruction was given to students in the treatment group, it is important to clarify how accuracy and appropriacy are defined in the present study.

Passive voice. It is clear from corpora that passive voice is frequently employed in academic writing (Biber, Conrad, \& Leech, 2002; Hinkel, 2002a); however, ELLs struggle with this complex structure (Hinkel, 2002a; 2002b; 2004; Williams \& Evans, 1998; Zhou, 1992). Passive voice is used to de-emphasize of the role of the agent and is formed with the auxiliary be and the past participle of the main verb. While passive construction can also be formed with the verb get and the 
past participle, it has been argued that this construction is categorically different (Mitkovoska \& Buzarovska, 2012). Use of the auxiliary be and past participle for passive voice can be constructed as either long or short passives. Long passives include a by-phrase which has the agent. Short passives omit the agent of the action from the sentence (Biber, Conrad, \& Leech, 2002). For example, the active sentence "Someone wrote in this book" becomes the short passive "This book was written in" or the long passive "This book was written in by someone." As previously noted, Hinkel (2002a) and Russell (2014) found that passive voice is used infrequently by ELLs. Hinkel's (2004) comparison of short ELL essays from six language groups (Arabic, Chinese, Indonesian, Japanese, Korean, Vietnamese) showed that the median frequency rate of passive voice for English L1 students was 1.32, while it ranged from 0.33 to 0.75 for ELLs. When passive voice is used, often there are form errors. As Russell (2014) found, intermediate ELLs often had form errors when they used passive voice, for example: "However, child abuse can also be passing by to the next generation," (Russell, 2014, p. 53).

Relative clauses. Relative clauses are frequently used in academic writing and reduced relative clauses are often used to condense information in academic prose (Biber, 1988). However, due to the advanced structure of reduced relative clauses, ELLs may avoid them or make errors when they attempt use (Hinkel, 2004). Reduced relative clauses have the same function as a full relative clause but omit elements of the clause (the relative pronoun and auxiliary be) without changing its meaning (Master, 2002). Reducing a relative clause may not be required in a 
sentence, but can be used by the writer to condense their writing (Master, 2002;

Hinkel, 2002b). Reduction of a relative clause is done by omitting the relative pronoun and using an -ed or -ing participle clause. Table 2.1 shows a reduced relative clause compared with the full relative clause.

Table 2.1: Full and reduced relative clauses

\begin{tabular}{|l|l|l|}
\hline & Reduced relative clause & Full relative clause \\
\hline $\begin{array}{l}\text {-ed } \\
\text { participle } \\
\text { clause }\end{array}$ & $\begin{array}{l}\text { "Obviously, when social } \\
\text { entrepreneurs invest their money in } \\
\text { businesses aimed primarily at solving } \\
\text { community problems, this may leads } \\
\text { to many benefits for communities and } \\
\text { potential changes" (1057AR). }\end{array}$ & $\begin{array}{l}\text { "Obviously, when social } \\
\text { entrepreneurs invest their } \\
\text { money in businesses that are } \\
\text { aimed primarily at solving } \\
\text { community problems...” }\end{array}$ \\
\hline $\begin{array}{l}\text {-ing } \\
\text { participle } \\
\text { clause }\end{array}$ & $\begin{array}{l}\text { "Clearly, when social change happens, } \\
\text { it effects the community's } \\
\text { development and the happiness of } \\
\text { the people living in that community" } \\
\text { (1056AR). }\end{array}$ & $\begin{array}{l}\text { “..the happiness of the } \\
\text { people who live in that } \\
\text { community." }\end{array}$ \\
\hline
\end{tabular}

Students may not understand this complex structure and create ill-formed sentences, for example: "Also, it can be good factor to decline in the proportion of students cheat" (1135AR). Hinkel (2002b) found that the use of full relative clauses was common in the L1 and ELL writing analyzed for her study. However, the use of reduced relative clauses, the more complex structure, was significantly lower for ELLs. Russell (2014) also found that the use full relative clauses was frequent in ELL writing, but many of those clauses would have been more effective if they were reduced. Here is one example from her study: "The two biggest aspect that are affected by ecotourism are the environment and indigenous people." This sentence 
contains a full relative clause, but it would be more effective if the writer had reduced it by omitting the relative pronoun and using an -ed participle clause. This makes the writing more concise and is highly valued in technical writing (Master, 2002).

Modal would. Modal verbs and hedging are important aspects of argumentative academic writing (Swales \& Feak, 2012; Hinkel, 2002b). Research has shown that modal verbs are necessary to create a strong argument structure in academic writing (Biber, 1988; Nash, 1990). Modal verbs are also used to hedge in academic writing, and hedging is an important component to create an academic tone; however, hedging devices are often lacking in ELL writing (Hyland \& Milton, 1997). ELLs are more likely than L1 writers to use devices that create direct, certain arguments in their writing (Skeleton, 1988). Hedging in academic texts is argued to strengthen the argument as it allows for a back-and-forth discourse between the writer and reader (Myers, 1989). Use of modal would in conditionals is also important in academic writing for many reasons including the way it structures arguments in an academic paper so as to make the claims easier for the reader to believe and or conclude on their own (Waschal, 2010). However, forming conditional sentences presents many challenges for ELLs. The additional use of modal would in conversational English for politeness strategies can lead to students applying this type of modal would in their academic writing. Russell (2014) found four uses of modal would in L1 and ELL writing: a hypothetical event or state, a future intention expressed in the past, a habitual characteristic behavior, and to 
express politeness or tentativeness. Russell identified that while both L1 and ELL papers made grammatical errors with modal would, ELL papers only employed two out of four uses of modal would in writing: ELLs most frequently used modal would to describe a hypothetical event or to show politeness (such as with a request or offer). Their use of modal would to express a future intention (past tense of will) or past habitual behavior was very infrequent.

Summary. Clearly, the use of passive voice, reduced relative clauses, and modal would is frequently found in academic writing, yet ELLs often do not use these features as frequently as L1 writers. They also may not form these features accurately, or may use them in an inappropriate way. With these findings, it is necessary to find ways to better instruct ELLs to use these features in their academic writing. Research can inform how to best teach grammar in the classroom so as to work towards improving ELLs' frequency, accuracy, and appropriate use of passive voice, reduced relative clauses, and modal would.

\section{Teaching Grammar for Academic Writing}

Research on grammar instruction is as vast as it is multi-focused. Research has not found the one correct way to teach grammar, but it has found evidence for many different successful approaches in certain settings, which will be described

next. Research supports that grammar instruction is more effective than input only (Norris \& Ortega, 2002), increased time and previous experience increase learner accuracy (Balcom \& Lee, 2009), consciousness raising and noticing of target forms lead to better acquisition (Nassaji \& Fotos), and mixed approaches (deductive and 
inductive; focus on form and focus on forms, etc) can be more effective than a single approach for all instruction (Ellis, 2006).

Norris and Ortega's (2002) meta-analysis of research findings for grammar instruction types sheds some light on the question of which approaches to grammar instruction are most effective. Prior to their analysis, there was serious debate as to whether grammar instruction was in fact more effective than simply being exposed to language and acquiring grammar as one acquires their first language. Importantly, Norris and Ortega (2002) found that grammar instruction does make consequential differences in L2 acquisition.

Amount of time of instruction and time practicing, in addition to prior instruction of a grammatical structure can also lead to more accurate use for ELLs. Balcom \& Lee (2009) showed that students who had more time learning about and practicing use of a grammatical structure did far better on a posttest. Further, students who had received prior instruction on that structure at some point in a language learning class performed better on a post-test than the students who were learning the structure for the first time.

Much research has shown that noticing or consciousness raising of grammatical structures leads to successful outcomes for learners and is an important factor in grammar instruction. Nassaji \& Fotos (2004) explain that prior research may not have identified the precise type of grammar instruction (e.g. focus on form, deductive, or explicit) which leads to the best acquisition outcomes for learners; however, it is clear that consciousness raising and noticing of target forms, 
input of the target forms that are meaning-centered, and increasing possibilities for output and practice are vital acquisition conditions.

Considering all of the data, many scholars have asserted that combining approaches to grammar, rather than picking one approach as the best way to teach grammar, leads to more success (Ellis 2006; Azar, 2007; Hinkel, 2004). In fact, using more approaches and having more time to practice using grammatical structures may lead to ELL academic papers which have more accurate forms and increased use of important grammatical features such as passive voice, reduced relative clauses and modal would.

It is clear from Hinkel (2002)'s research that ELLs are infrequently using these important academic features. Russell (2014)'s research at Portland State University's IELP showed that ELLs compared to L1 students in the university also have marked differences in frequency and accuracy of these important features, particularly including passive voice, reduced relative clause, and modal would. Although these studies clearly show important differences between ELL and L1 writing, research has yet to examine whether focused grammar instruction in these specific grammar features can lead to greater frequency, accuracy, or appropriacy in their use in ELL writing.

To investigate if more focused instruction on noticing, distinguishing, practicing, and extended time with these features increases and/or improves ELL use of passive voice, reduced relative clauses, and modal would an experiment was designed. Two instructors in the program where Russell's study was conducted 
integrated her recommendations into the advanced grammar curriculum. The present study was designed to determine whether the students who received the intervention instruction used the target features more frequently, accurately, and appropriately in their academic essays than those who did not. ELL essays were collected from a control group in PSU's IELP's guided research writing class and a treatment group also in PSU's IELP's guided research writing class. Students in the control group received the same instruction type and amount of time in their grammar class with passive voice, reduced relative clauses, and modal would as the students in Russell's (2014) study. The students in the treatment group were given more time and supplementary practice with passive voice, reduced relative clauses, and modal would in their advanced grammar class. This study investigates the following:

Are there any differences in frequency, accuracy, or appropriacy of use of three target grammatical features (passive voice, reduced relative clauses, and modal would) between the control group and the treatment group after the grammar instruction? 


\section{Chapter 3: Methodology}

\section{Context of Study}

This study analyzed the use of three grammatical features (passive voice, reduced relative clauses, and modal would) in research essays written by advanced students in an intensive English program at a public university in the Pacific Northwest. The essays were part of a guided-research writing class taken the same term as an advanced grammar class. The control group were enrolled in the advanced grammar class with traditional instruction as described in Russell (2014). The treatment group was enrolled in the advanced grammar class and was given focused instruction and more time in class spent noticing, distinguishing, practicing, and producing three specific grammatical features: passive voice, reduced relative clauses, and modal would. The treatment instruction was taught by two faculty members during one term. The faculty members met together to discuss materials and lesson plans prior to and during the term. One faculty member was the author of the previous study investigating these features in this context (Russell, 2014). This was her first term teaching grammar in this setting. The other faculty member has taught this grammar class multiple times over ten years of teaching. The researcher observed the advanced grammar level 4 class so as to better understand instruction methods of the control group.

\section{Participants}

Portland State University's Intensive English Language Program (PSU's IELP) has five standard levels of instruction and a sixth for advanced students taking 
specialized elective courses. All of the essays for this study were written by students who had successfully passed level 3 writing and grammar at PSU's IELP or had taken a placement exam (known as the Institutional TOEFL exam, level 2) and were placed into level 4 advanced grammar and level 4 guided-research writing. The L1 backgrounds of the participants were mixed: Arabic, Chinese, Farsi, Hindi, Japanese, Korean, and Portuguese.

\section{Materials and Instruments}

There were 44 essays analyzed for the control group and 25 essays analyzed for the experimental group. The average word length of the essays for each group is 840 and 998 respectively. There was one essay for each participant. The essay topics differed, but the rubric was the same for each student. The topics included making a change (social justice), plagiarism and cheating, and racism.

Table 3.1: Essay topic distribution

\begin{tabular}{|l|l|l|}
\hline Essay topic & \# of control essays & \# of treatment essays \\
\hline Making a change (social justice) & 27 & 0 \\
\hline Plagiarism and cheating & 14 & 20 \\
\hline Racism & 3 & 5 \\
\hline
\end{tabular}

\section{Data Collection}

Essays were collected after the Fall 2013, Winter 2014 and Spring 2014 terms in the Intensive English Language Program. They were collected for a separate study being conducted by an IELP faculty member (HSRRC Proposal \#132709) and were re-analyzed for this study (IRB \#153647). 


\section{Treatment Instruction}

Passive voice. Students in the treatment group received extended time and instruction on passive voice (Table 3.2). As part of the extended instruction, students in the treatment group had additional assignments in class and as homework. Students in the control group typically receive 2.5 days on instruction of passive voice; treatment group students were given three days on passive voice.

Table 3.2: Description of passive voice control and treatment instruction

\begin{tabular}{|l|l|l|}
\hline Passive voice & \multicolumn{1}{|c|}{ Control } & \multicolumn{1}{c|}{ Treatment } \\
\hline $\begin{array}{l}\text { Days of } \\
\text { instruction }\end{array}$ & 2.5 days passive voice & 3 days passive voice \\
\hline $\begin{array}{l}\text { Types of } \\
\text { exercises }\end{array}$ & $\begin{array}{l}\text { In-class work } \\
\text { 4 assignments: grammar } \\
\text { exercises in books (Azar, FOG } \\
4 \text { ) }\end{array}$ & $\begin{array}{l}\text { In-class work } \\
7 \text { assignments: 2 included } \\
\text { noticing, 6 included changing } \\
\text { a sentence from active to } \\
\text { passive, 3 prompted } \\
\text { production of passive voice } \\
\text { sentences, 1 had students } \\
\text { attend to reasons of usage }\end{array}$ \\
\hline
\end{tabular}

In one assignment, the treatment group students were required to read an academic article and mark all of the verbs. Then, they worked with a partner to separate which verbs were active and which were passive. Students were directed to look at the active verbs and note the relationship of the subject to the action. Then, they were to do the same for the passive verbs. This was designed to help students attend to appropriacy of use. After this, students were given three active sentences and had to change them to passive. This task had students working 
on forming passive voice accurately. The final step for this assignment was to change passive sentences selected by the teacher to active voice.

Another assignment started with a prompt to review what passive voice is, how to form it grammatically, and what the words by-phrase, agent, and active voice mean. Next, students were given four active voice sentences that were formed from passive verbs in an academic text from their guided-research writing class. They were directed to find the corresponding passive voice sentences in the text, rewrite them next to the active voice sentences, and underline the passive verb. The next step was for students to write short answers explaining why they believe the author used the passive rather than the active for certain sentences.

One activity focused on by-phrases. Students were asked to count the number of by-phrases in a familiar text. Then they were given examples of common non-human by-phrases in academic writing, asked to underline by-phrases in a sample text, and then were given active sentences for them to practice forming passive sentences with by-phrases. The object of the passive sentence was provided for students. The final task was for students to answer provided questions (such as "How can learning be supported?") with their own ideas and use passive voice and a non-human by-phrase. The next step of this activity was a fill-in-the-blank worksheet which focused on other common prepositions used with passive voice.

Students in the treatment group were also given a homework assignment which required them to choose the correct verb form (passive infinitive or gerund) for pre-written sentences and then change underlined portions of sentences to 
passive voice. In addition to this, treatment group students were also given in-class practice worksheets (one more scaffolded and two less scaffolded) with active sentences and asked to change them to passive voice. They also received an in-class worksheet and were asked to discuss examples sentences with a partner and then paraphrase them using passive voice. Finally, students in the treatment group were given a production task to write about one of the topics from their book and use passive voice at least six times (among two other features they were currently studying in class).

Reduced relative clauses. Students in the treatment group received extended time and instruction on relative clauses. As part of the extended instruction, students in the treatment group had additional assignments in-class and as homework. Students in the control group typically receive 1.5 days on instruction of reduced relative clauses; treatment group students were given 2.5 days on reduced relative clauses.

Table 3.3: Description of reduced relative clause control and treatment instruction

\begin{tabular}{|l|l|l|}
\hline $\begin{array}{l}\text { Reduced } \\
\text { relative clauses }\end{array}$ & \multicolumn{1}{|c|}{ Control } & \multicolumn{1}{c|}{ Treatment } \\
\hline $\begin{array}{l}\text { Days of } \\
\text { instruction }\end{array}$ & $\begin{array}{l}\text { (1 day full relative } \\
\text { clauses) } \\
1.5 \text { days reduced relative } \\
\text { clauses }\end{array}$ & $\begin{array}{l}\text { (1 day full relative clauses) } \\
\text { cla days reduced relative } \\
\text { clauses }\end{array}$ \\
\hline $\begin{array}{l}\text { Types of } \\
\text { exercises }\end{array}$ & $\begin{array}{l}\text { In-class work } \\
1 \text { homework assignment }\end{array}$ & $\begin{array}{l}\text { In-class work } \\
\text { assignments: 2 included } \\
\text { identifying, 1 included change } \\
\text { full to reduced, 2 prompted } \\
\text { production, 1 had students } \\
\text { attend to reasons of usage }\end{array}$ \\
\hline
\end{tabular}


Four assignments focused on or included practice with reduced relative clauses. One assignment instructed students to read through an academic article and highlight all of the -ing forms they found. Then, students were asked to separate these -ing forms into six categories: gerunds, reduced relative clauses, reduced adverb clauses, adjectives (before a noun), regular progressive verbs, or other. After this task, students were asked which -ing form was the most common, why they thought the author chose to use reduced relative clauses instead of full relative clauses, and asked if they use reduced relative clauses in their writing. If they answered that they did not, they were prompted explain whether they think they will now. This assignment was designed for students to attend primarily to appropriacy and encourage students to think about their own frequency of use in writing.

A second assignment included a task in which students bracketed the relative clause and identified if the relative pronoun was a subject or object. Then, they were prompted to bracket the relative clauses in a paragraph and finally to choose two of those relative clauses and reduce them. This task had students practice accuracy of forming reduced relative clauses. A third assignment was a review. It gave students 17 sentences with -ing and asked them to identify what the -ing is doing in the sentence. Next, they had to list four different ways -ing can be used, and finally they were asked to write a sentence for each of the following types of -ing which they had studied: gerund as a subject, gerund as the object of a verb, gerund 
as the object of a preposition, reduced relative clause, and reduced adverb clause. The last assignment that included reduced relative clauses was a written production assignment. Students were prompted to answer provided questions with a certain number of relative clauses (full and reduced).

Modal would. Students in the treatment group received extended time and instruction on modal would. As part of the extended instruction, students in the treatment group had additional assignments in class and as homework. Students in the control group typically receive 3 days on instruction of modal would; treatment group students were given 4 days on modal would.

Table 3.4: Description of modal would control and treatment instruction

\begin{tabular}{|l|l|l|}
\hline Modal would & \multicolumn{1}{|c|}{ Control } & \multicolumn{1}{c|}{ Treatment } \\
\hline $\begin{array}{l}\text { Days of } \\
\text { instruction }\end{array}$ & $\begin{array}{l}\text { 3 days: 0.5 on } \\
\text { past modals, } \\
2.5 \text { on } \\
\text { conditionals }\end{array}$ & $\begin{array}{l}\text { 4 days: 1 on conditionals, modals, and } \\
\text { hedges; } 1 \text { on present/past modals; 0.5 on } \\
\text { uses of would; 1.5 on past unreal conditionals }\end{array}$ \\
\hline $\begin{array}{l}\text { Types of } \\
\text { exercises }\end{array}$ & $\begin{array}{l}\text { In-class work } \\
\text { No } \\
\text { assignments } \\
\text { listed }\end{array}$ & $\begin{array}{l}\text { In-class work } \\
\text { a assignments: 1 included noticing, 2 } \\
\text { included identifying, 4 prompted production, } \\
1 \text { had students attend to reasons of usage }\end{array}$ \\
\hline
\end{tabular}

Two assignments practicing correct verb tense with modal would and other hypotheticals. One assignment explained Russell's (2014) findings in regard to modal would, followed by a noticing and discussion activity with examples of would from academic texts. Students were given examples from corpora and asked to identify if it was a conversational use of would or an academic use of would. Students were given four meanings of the use of modal would (hypothetical 
situation or possibility, future in past tense, habitual past action, and politeness) and asked to mark whether the meaning was associated with conversation or academic writing. This assignment was designed for students to take note of appropriate uses of would. The next step showed students three sentences from Russell's (2014) study and asked them to highlight modal would and answer three questions: which use of would is correctly used in the academic writing, which sentence(s) are incorrect for writing purposes, and can you think of better ways to use would in the incorrect sentences. Students were given practice after this activity identifying the kind of modal would being used in nine example sentences. They were directed afterwards to look at the hypothetical sentences' use of if and explain why it is always used.

Another activity the treatment group was given was to practice categorizing and then creating conditional sentences, which included modal would. Students in the treatment group were also given a quiz on conditionals. Students were required to fill-in-the-blank with the correct verb tense and modal, correct errors (which included incorrect and missing use of modal would), and produce sentences by answering two hypothetical questions. This activity had students attending to accurate form of modal would. Finally, students in the treatment group were given a written production assignment which required them to use conditional sentences.

\section{Analysis Procedures}

The essays were anonymized to eliminate information about the students' identities. The essays were manually tagged as defined above for grammatical, 
ungrammatical, appropriate, and inappropriate usage of the features passive voice, reduced relative clauses, and modal would. The attempts of each category were hand-counted and normed per 1,000 words per paper. The frequency of attempts of each feature were compared between the control and treatment group to answer research question one. The accuracy of use of the three features was found by calculating the number of correct form-based attempts out of the total attempts and compared between the control and treatment group to answer research question two. The appropriacy of use for the three features was found by calculating the number of appropriately used attempts out of total attempts and compared between the control group and treatment group to answer research question three. The data for frequency of passive voice were normally distributed and analyzed using an independent t-test. The data for frequency of reduced relative clauses and modal would were not normally distributed, as were the results for accuracy and appropriacy of use for all three features. A Mann-Whitney U test was run for those features. 


\section{Chapter 4: Results}

Results comparing the treatment and control group for frequency, accuracy, and appropriacy showed there were no statistical differences between the two groups. For frequency of passive voice, students in the treatment group had a higher mean of instances than students in the control group, but it was not a statistically significant difference. Frequency of reduced relative clauses and modal would were not significantly different between the treatment and control group-in fact, frequency of reduced relative clauses and modal would overall was low. Accuracy and appropriacy of passive voice between the treatment and control group were not significantly different. As noted, reduced relative clauses and modal would were infrequently used by students in the treatment and control group; however, when students used these features they almost always used them accurately and appropriately in both the treatment and control groups.

\section{Data Coding Procedures}

Passive voice. Tagging for grammatical form was defined as use of passive voice, with or without the by-phrase, formed by using auxiliary be followed by a past participle which serves as the main verb. Tagging for ungrammatical form was defined as missing auxiliary be in a passive construction, verb tense/aspect error in a passive construction, verb form error with a passive construction, or subject-verb agreement error in a passive construction. Appropriate usage was defined as obeying the proper order of information structure and use of passive voice with patient in subject position. Inappropriate usage was defined as use of passive voice 
with the agent in the subject position and copular or intransitive verb usage with a passive construction.

Reduced relative clauses. Tagging for grammatical form was defined as a reduced relative clause with a post-nominal participle clause -ed/past participle or -ing (Biber, Conrad, \& Leech, 2002). Tagging for ungrammatical form was defined as participle clause form error. Appropriate usage was defined as a reduced relative clause with post-nominal participle clause-ed/past participle for passive construction or -ing for active construction (Biber, Conrad, \& Leech, 2002) and information is "firmly established, highly typical, and widely generalizable," Vande Kopple, 2998, p.190). Alternately, inappropriate usage was defined as information not "firmly established, highly typical, and widely generalizable," (Vande Kopple, 1998, p.109), Post nominal participle clause uses past participle with an intransitive verb, and/or post-nominal participle clause uses past participle in an active construction.

Modal would. Tagging for grammatical form was defined as use of modal would with the base form of the main verb. Tagging for ungrammatical form was defined as modal error when referencing past or future time (will instead of past would or would instead of will), and incorrect form of main verb after would. Appropriate usage was defined as use of modal would when required for a present or past conditional. Inappropriate usage was defined as use of a different modal when would is required for a present or past conditional sentence, absence of modal 
would when required in a present or past conditional, and use of modal would as a politeness strategy. 
Table 4.1: Passive voice data coding procedures

\begin{tabular}{|c|c|c|}
\hline Category & Definition & Examples from learner corpus \\
\hline $\begin{array}{l}\text { Grammatical } \\
\text { form } \\
\text { (frequency) } \\
<\mathrm{PV}>\end{array}$ & $\begin{array}{l}\text { Use of passive } \\
\text { voice with or } \\
\text { without the by- } \\
\text { phrase, formed by } \\
\text { using auxiliary be } \\
\text { followed by a past } \\
\text { participle which } \\
\text { serves as the main } \\
\text { verb }\end{array}$ & $\begin{array}{l}\text { During India independence movement, } \\
\text { Gandhi was jailed in a prison many times } \\
\text { because Briton wanted him out of the way } \\
\text { but could not kill him, despite this Gandhi } \\
\text { kept fighting (1059KO). } \\
\text { The reason why they did that is that they } \\
\text { refused to be ruled by the new government } \\
(1077 \mathrm{CH}) \text {. }\end{array}$ \\
\hline $\begin{array}{l}\text { Ungrammatical } \\
\text { form (form } \\
\text { error) } \\
<\mathrm{PV} \mathrm{X}>\end{array}$ & $\begin{array}{l}\text { 1. Missing } \\
\text { auxiliary be } \\
\text { 2. Verb } \\
\text { tense/aspect error } \\
\text { 3. Verb form error } \\
\text { 4. Subject-verb } \\
\text { agreement error }\end{array}$ & $\begin{array}{l}\text { 1. DuVall (2004) states that non-violent } \\
\text { movement's assistance should spread all } \\
\text { over the country by many small groups and } \\
\text { by leaders involving people in only slight } \\
\text { risks (1084HI). } \\
\text { 2a. In other words, his illness is increased } \\
\text { due to doping which cause latter cancer on } \\
\text { his blood (1163AR). } \\
2 \mathrm{~b} \text {. When one country is being just known } \\
\text { by its successes, it is not an idea of identity } \\
\text { (1147PO). } \\
\text { 3. People all glad that Yanukovych has been } \\
\text { deporting and people finally got rid of him } \\
\text { (1074CH). } \\
\text { 4. I think if PEDS was legalized, we could } \\
\text { open a door with many problem we cannot } \\
\text { control (1124AR). }\end{array}$ \\
\hline $\begin{array}{l}\text { Appropriate } \\
\text { usage } \\
<\text { PV A }>\end{array}$ & $\begin{array}{l}\text { 1. Obeys proper } \\
\text { order of } \\
\text { information } \\
\text { structure } \\
\text { 2. Use of passive } \\
\text { voice with patient } \\
\text { in subject position; }\end{array}$ & $\begin{array}{l}\text { 1. A successful non-violent movement must } \\
\text { have very clear goals [...] Jack ( } 2004) \text { states } \\
\text { that clear goals must be shown by people } \\
\text { of a civilian based protest to reflect } \\
\text { people's demands to the regime (1072AR). }\end{array}$ \\
\hline
\end{tabular}




\begin{tabular}{|c|c|c|}
\hline & $\begin{array}{l}\text { patient is focus of } \\
\text { sentence }\end{array}$ & $\begin{array}{l}\text { 2. The president would not have been } \\
\text { ousted if the Ukraine movement was not } \\
\text { strong enough (1068AR). }\end{array}$ \\
\hline $\begin{array}{l}\text { Inappropriate } \\
\text { usage (use } \\
\text { error) } \\
<\text { PV AX> }\end{array}$ & $\begin{array}{l}\text { 1. Use of passive } \\
\text { voice with the } \\
\text { agent in the } \\
\text { subject position } \\
\text { 2. Copular or } \\
\text { intransitive verb } \\
\text { used with passive } \\
\text { construction. }\end{array}$ & $\begin{array}{l}\text { 1. Researchers has been found some side } \\
\text { effects of the uses of PEDS (1124AR). } \\
\text { 2a. Many leaders want to gain good place in } \\
\text { their follower's hearts. Mostly they tend to } \\
\text { identify them by the follower's morals and } \\
\text { thoughts. These leaders are considered in } \\
\text { our society and this makes them to be long } \\
\text { famous. } \\
\text { 2b. A second reason for racism still being } \\
\text { present in our days is that it is raised in our } \\
\text { identity. }\end{array}$ \\
\hline
\end{tabular}

Table 4.2: Reduced relative clauses data coding procedures

\begin{tabular}{|c|c|c|}
\hline Category & Definition & Examples from learner corpus \\
\hline $\begin{array}{l}\text { Grammatical } \\
\text { form } \\
\text { (frequency) } \\
<\text { R REL }>\end{array}$ & $\begin{array}{l}\text { Reduced relative } \\
\text { clause with post- } \\
\text { nominal participle } \\
\text { clause -ed or -ing } \\
\text { (Hinkel, 2002b; } \\
\text { Master, 2002) }\end{array}$ & $\begin{array}{l}\text { Shah (2010) points out that Charles } \\
\text { Darwin's theories are misunderstood and } \\
\text { used to claim that specific traits such as } \\
\text { intelligence, are confined to specific races } \\
\text { depending on a false biological basis } \\
\text { (1146AR). } \\
\text { Every culture contains heroes who have } \\
\text { characteristics related to that culture } \\
(1066 \mathrm{AR}) .\end{array}$ \\
\hline $\begin{array}{l}\text { Ungrammatical } \\
\text { form (form } \\
\text { error) } \\
\text { <R REL X> }\end{array}$ & $\begin{array}{l}\text { 1. Participle clause } \\
\text { form error }\end{array}$ & $\begin{array}{l}\text { 1. Also, it can be good factor to decline in } \\
\text { the proportion of students cheat } \\
(1135 \mathrm{AR}) \text {. }\end{array}$ \\
\hline $\begin{array}{l}\text { Appropriate } \\
\text { usage } \\
\text { <R REL A> }\end{array}$ & $\begin{array}{l}\text { 1. Reduced relative } \\
\text { clause with post- } \\
\text { nominal participle } \\
\text { clause -ed/past } \\
\text { participle for }\end{array}$ & $\begin{array}{l}\text { 1. In conclusion, the attitude assumed by } \\
\text { the majority of students in cheating has } \\
\text { become something almost uncontrollable } \\
(1040 \mathrm{P} 0) \text {. }\end{array}$ \\
\hline
\end{tabular}




\begin{tabular}{|c|c|c|}
\hline & $\begin{array}{l}\text { passive } \\
\text { construction or - } \\
\text { ing for active } \\
\text { construction } \\
\text { (Hinkel, 2002b; } \\
\text { Master, 2002) } \\
\text { 2. Information is } \\
\text { "firmly established, } \\
\text { highly typical, and } \\
\text { widely } \\
\text { generalizable" } \\
\text { (Vande Kopple, } \\
\text { 1998, p. 190) }\end{array}$ & $\begin{array}{l}\text { 2. All "heroes" in context are literally the } \\
\text { group of people who facilitate social } \\
\text { developments, spreading positive energy } \\
\text { to the public }(1063 \mathrm{CH})\end{array}$ \\
\hline $\begin{array}{l}\text { Inappropriate } \\
\text { usage (use } \\
\text { error) } \\
\text { <R REL AX> }\end{array}$ & $\begin{array}{l}\text { 1. Information is } \\
\text { not "firmly } \\
\text { established, highly } \\
\text { typical, and widely } \\
\text { generalizable" } \\
\text { (Vande Kopple, } \\
\text { 1998, p. 190) } \\
\text { 2. Post-nominal } \\
\text { participle clause } \\
\text { uses past participle } \\
\text { with an intransitive } \\
\text { verb } \\
\text { 3. Post-nominal } \\
\text { participle clause } \\
\text { uses past participle } \\
\text { in an active } \\
\text { construction }\end{array}$ & $\begin{array}{l}\text { 1. (No instances present in data set.) } \\
\text { 2. According to the historical records, } \\
\text { there are many innocent people died in the } \\
\text { war }(1074 \mathrm{CH}) \text {. } \\
\text { 3. Biggest demonstration was about } \\
800,000 \text { people joined demonstration in } \\
\text { Kiev }(1174 \mathrm{CH})\end{array}$ \\
\hline
\end{tabular}


Table 4.3: Modal would data coding procedures

\begin{tabular}{|c|c|c|}
\hline Category & Definition & Examples from learner corpus \\
\hline $\begin{array}{l}\text { Grammatical } \\
\text { form } \\
\text { (frequency) } \\
<\text { WD> }\end{array}$ & $\begin{array}{l}\text { Use of modal } \\
\text { would with the } \\
\text { base form of the } \\
\text { main verb }\end{array}$ & $\begin{array}{l}\text { Another reason for not legalizing PED's in } \\
\text { sports is that it would change the } \\
\text { definition of sport (1255P0). }\end{array}$ \\
\hline $\begin{array}{l}\text { Ungrammatical } \\
\text { form (form } \\
\text { error) } \\
<\text { WD X> }\end{array}$ & $\begin{array}{l}\text { 1. Modal error } \\
\text { when referencing } \\
\text { past or future } \\
\text { time (will instead } \\
\text { of past would or } \\
\text { would instead of } \\
\text { will) } \\
\text { 2. Incorrect form } \\
\text { of main verb after } \\
\text { would }\end{array}$ & $\begin{array}{l}\text { 1. When famous athletes using PEDS for a } \\
\text { long time and are caught, people would be } \\
\text { disappointed and cannot trust other clean } \\
\text { athletes (Deford, 2012). (1124AR) } \\
\text { 2. (No instances present in data set) }\end{array}$ \\
\hline $\begin{array}{l}\text { Appropriate } \\
\text { usage } \\
\text { <WD A }>\end{array}$ & $\begin{array}{l}\text { Use of modal } \\
\text { would when } \\
\text { required for a } \\
\text { present or past } \\
\text { conditional }\end{array}$ & $\begin{array}{l}\text {...if drug use were legalized it would be } \\
\text { very difficult to forbid young athletes do } \\
\text { use it... (1125PO). }\end{array}$ \\
\hline $\begin{array}{l}\text { Inappropriate } \\
\text { usage (use } \\
\text { error) } \\
\text { <WD AX> }\end{array}$ & $\begin{array}{l}\text { 1. Use of a } \\
\text { different modal } \\
\text { when would is } \\
\text { required for a } \\
\text { present or past } \\
\text { conditional } \\
\text { sentence } \\
\text { 2. Absence of } \\
\text { modal would } \\
\text { when required in } \\
\text { present or past } \\
\text { conditional } \\
\text { 3. Use of modal } \\
\text { would as a } \\
\text { politeness } \\
\text { strategy }\end{array}$ & $\begin{array}{l}\text { 1. If using PEDS was legalized, the basic } \\
\text { meaning of sports should change. } \\
\text { 2. [...] if they discovered an athlete takes } \\
\text { performance enhancing drugs and _- } \\
\text { consider him as cheater (1131AR). } \\
\text { 3. This is the idea that I would first like to } \\
\text { expand upon because it gives evidence of } \\
\text { the fact that when intelligence... (1080AR) }\end{array}$ \\
\hline
\end{tabular}




\section{Research Question 1}

Are there any differences in frequency of use of three target grammatical features (passive voice, reduced relative clauses, and modal would) between the control group and the treatment group after the grammar instruction?

Table 4.4: Frequency of features in treatment and control groups

\begin{tabular}{|c|c|c|c|}
\hline & \multicolumn{2}{|c|}{$\begin{array}{c}\text { Frequency: mean } \\
\text { instances/paper }\end{array}$} & \\
\cline { 2 - 4 } & Treatment & Control & $\mathrm{p}$-value \\
\hline Passive voice & 9.22 & 8.13 & $\begin{array}{c}\text { Independent t- } \\
\text { test: } \mathrm{p}=0.355\end{array}$ \\
\hline $\begin{array}{c}\text { Reduced relative } \\
\text { clauses }\end{array}$ & 1.74 & 1.43 & $\begin{array}{c}\text { Mann-Whitney U } \\
\text { test: } \mathrm{p}=0.591\end{array}$ \\
\hline Modal would & 1.47 & 0.92 & $\begin{array}{c}\text { Mann-Whitney U } \\
\text { test: } \mathrm{p}=0.352\end{array}$ \\
\hline
\end{tabular}

Passive voice. Data for frequency of passive voice were normally distributed on a histogram and Levene's Test for Equality of Variances $\mathrm{p}=0.143$ showed the data were parametric. Results from an independent $\mathrm{t}$-test showed that the differences between the frequency of passive voice between the treatment $(n=25)$ and control group $(n=44)$ were not statistically significant $(p=0.355)$. The mean for the treatment group was 9.22 instances (SD: 5.643) with a max of 23 and a min of 0 . The mean for the control group was 8.13 instances (SD: 4.003) with a max of 22 and a min of 1 . Although an independent t-test determined the results were 
not statistically significant, the papers from the treatment group did have a slightly higher mean of instances of passive voice formed than papers in the control group.

Table 4.5: Frequency statistics for passive voice

\begin{tabular}{|l|l|l|l|l|}
\hline \multicolumn{5}{|c|}{ Frequency: Passive voice } \\
\hline & Mean & Min & Max & SD \\
\hline Treatment & 9.22 & 0 & 21.53 & 5.643 \\
\hline Control & 8.14 & 1.14 & 17.40 & 4.003 \\
\hline
\end{tabular}

Reduced relative clauses. Data for frequency of reduced relative clauses were non-parametric. The results from a Mann-Whitney U Test show that frequency of reduced relative clauses is distributed the same across both the treatment and control group $(\mathrm{p}=0.591)$ meaning there was no statistical difference between the two groups. The reduced relative clause structure was often not present. The treatment group $(n=25)$ had a mean of 1.74 instances with a standard deviation of 2.101. The maximum and minimum were 7 and 0 respectively. The control group $(\mathrm{n}=44)$ had a mean of 1.43 instances $(\mathrm{SD}=1.729)$ with a maximum of 5 and a minimum of 0.

Table 4.6: Frequency statistics for reduced relative clauses

\begin{tabular}{|l|l|l|l|l|}
\hline \multicolumn{5}{|c|}{ Frequency: Reduced relative clauses } \\
\hline & Mean & Min & Max & SD \\
\hline Treatment & 1.74 & 0 & 7.51 & 2.101 \\
\hline Control & 1.43 & 0 & 5.31 & 1.729 \\
\hline
\end{tabular}

Modal Would. These data were also non-parametric and the results from a Mann-Whitney U Test show that the difference in frequency of modal would for the treatment and control group was not statistically significant $(\mathrm{p}=0.352)$. It should be noted that less than half of the students for each group attempted to use modal 
would in their writing. The treatment group $(\mathrm{n}=25)$ had a mean of 1.47 instances $(\mathrm{SD}=1.997)$. The max and min were 8 and 0 respectively. The control group $(\mathrm{n}=44)$ had a mean of 0.92 instances (standard deviation=1.064) with a max of 5 and a min of 0 .

Table 4.7: Frequency statistics for modal would

\begin{tabular}{|l|l|l|l|l|}
\hline \multicolumn{5}{|c|}{ Frequency: Modal would } \\
\hline & Mean & Min & Max & SD \\
\hline Treatment & 1.47 & 0 & 12.3 & 1.997 \\
\hline Control & 0.92 & 0 & 7.32 & 1.06 \\
\hline
\end{tabular}

\section{Research Question 2}

Are there any differences in accuracy of use of three target grammatical features (passive voice, reduced relative clauses, and modal would) between the control group and the treatment group after the grammar instruction?

Data were collected for both number of instances in which a feature was formed accurately and number of instances in which use of a feature was inaccurately formed. The number of accurately formed attempts was divided by total attempts to find the accuracy percentage.

Table 4.8: Accuracy of features in treatment and control groups

\begin{tabular}{|c|c|c|c|}
\hline \multirow{2}{*}{} & \multicolumn{2}{|c|}{ Accuracy: mean \% } & \\
\cline { 2 - 4 } & Treatment & Control & $\mathrm{p}$-value \\
\hline Passive voice & $90.19 \%$ & $91.47 \%$ & $\begin{array}{c}\text { Mann-Whitney } \\
\text { U test: } \mathrm{p}=0.307\end{array}$ \\
\hline $\begin{array}{c}\text { Reduced relative } \\
\text { clauses }\end{array}$ & $96.87 \%$ & $94.82 \%$ & $\begin{array}{c}\text { Mann-Whitney } \\
\text { U test: } \mathrm{p}=0.913\end{array}$ \\
\hline Modal would & $97.2 \%$ & $77.4 \%$ & $\begin{array}{c}\text { Mann-Whitney } \\
\text { U test: } \mathrm{p}=0.212\end{array}$ \\
\hline
\end{tabular}


Passive voice. A Mann-Whitney $\mathrm{U}$ test showed the treatment and control group are similar in the number of inaccurate forms of passive voice $(\mathrm{p}=$ 0.307). From this result, one cannot conclude that the treatment affected how accurately students formed passive voice in their writing. Treatment group students had a mean of $90.19 \%$ form-based accuracy with passive voice $(\mathrm{SD}=23.36 \%)$ with a maximum of $100 \%$ and minimum of $0 \%$. The minimum of $0 \%$ is attributed to one student who attempted to use passive voice a single time in their essay, but did not form it accurately. The second minimum was $44 \%$. Students in the control group had a mean of $91.47 \%$ accuracy with forms for passive voice ( $\mathrm{SD}=11.83 \%$ ), a maximum of $100 \%$ and a minimum of $55.56 \%$.

Table 4.9: Accuracy statistics for passive voice

\begin{tabular}{|l|l|l|l|l|}
\hline \multicolumn{5}{|c|}{ Accuracy: Passive voice } \\
\hline & Mean & Min & Max & SD \\
\hline Treatment & $90.19 \%$ & $0 \%$ & $100 \%$ & $23.36 \%$ \\
\hline Control & $91.47 \%$ & $55.56 \%$ & $100 \%$ & $11.83 \%$ \\
\hline
\end{tabular}

Reduced relative clauses. The Mann-Whitney U test concluded there is no significant difference between the two groups $(\mathrm{p}=0.913)$ for accuracy of reduced relative clauses. As previously noted, students in both groups rarely used this structure (mean of 1.72 instances per paper for both groups combined) but when used, the students in the treatment and control groups made very few form-based errors when they attempted the reduced relative clause structure. Treatment group students had a mean of $96.87 \%$ (SD=12.5\%) while control group students had a mean of $94.82 \%(\mathrm{SD}=20.46 \%)$. The maximum and minimum for the treatment 
group was $100 \%$ and 50\%; the maximum and minimum for the control group was $100 \%$ and $0 \%$.

Table 4.10: Accuracy statistics for reduced relative clauses

\begin{tabular}{|l|l|l|l|l|}
\hline \multicolumn{5}{|c|}{ Accuracy: Reduced relative clause } \\
\hline & Mean & Min & Max & SD \\
\hline Treatment & $96.87 \%$ & $50 \%$ & $100 \%$ & $12.5 \%$ \\
\hline Control & $94.82 \%$ & $0 \%$ & $100 \%$ & $20.46 \%$ \\
\hline
\end{tabular}

Modal Would. Very few instances of a form-based error with modal would were found in the data. According to the Mann-Whitney U test, accuracy of the use of modal would between the treatment and control group was not statistically significant $(\mathrm{p}=0.212)$. It cannot be concluded that the treatment instruction affected the accuracy of students' production of modal would in their papers. Mean accuracy for the treatment group was $97.2 \%$ (SD=9.622\%; $\max : 100 \%$, min: 66.67\%); mean accuracy for the control group were $77.4 \%$ (SD=38.265\%, $\max : 100 \%$, $\min : 0 \%)$.

Table 4.11: Accuracy statistics for modal would

\begin{tabular}{|l|l|l|l|l|}
\hline \multicolumn{5}{|c|}{ Accuracy: Modal would } \\
\hline & Mean & Min & Max & SD \\
\hline Treatment & $97.2 \%$ & $66.67 \%$ & $100 \%$ & $9.622 \%$ \\
\hline Control & $77.4 \%$ & $0 \%$ & $100 \%$ & $38.265 \%$ \\
\hline
\end{tabular}

\section{Research Question 3}

Are there any differences in appropriate usage of three target grammatical features (passive voice, reduced relative clauses, and modal would) between the control group and the treatment group after the grammar instruction? 
Table 4.12: Appropriacy of features in treatment and control groups

\begin{tabular}{|c|c|c|c|}
\hline \multirow{2}{*}{} & \multicolumn{2}{|c|}{ Appropriacy: mean \% } & \\
\cline { 2 - 4 } & Treatment & Control & $\mathrm{p}$-value \\
\hline Passive voice & $96.87 \%$ & $94.68 \%$ & $\begin{array}{c}\text { Mann-Whitney U } \\
\text { test: } \mathrm{p}=0.496\end{array}$ \\
\hline Reduced relative clauses & $93.75 \%$ & $97.93 \%$ & $\begin{array}{c}\text { Mann-Whitney U } \\
\text { test: } \mathrm{p}=0.642\end{array}$ \\
\hline Modal would & $95.19 \%$ & $82.63 \%$ & $\begin{array}{c}\text { Mann-Whitney U } \\
\text { test: } \mathrm{p}=0.540\end{array}$ \\
\hline
\end{tabular}

Data were collected for both number of instances in which a feature was used appropriately and number of instances in which use of a feature was inappropriately used. The number of appropriately used attempts was divided by the total of attempts to find the appropriate usage percentage.

Passive voice. Data for the number of instances of inappropriate passive voice use were non-parametric and a Mann-Whitney U test showed that the differences between the two groups were not statistically significant $(p=0.496)$. The treatment group had a mean of $96.87 \%(S D=5.174 \%)$ for instances of passive voice which were appropriate while the control group had a mean of $94.68 \%$ ( $\mathrm{SD}=16.46 \%$ ). The maximum for the treatment group was $100 \%$; the minimum was $85.71 \%$. For the control group, the maximum was $100 \%$, and the minimum was $0 \%$. 
Table 4.13: Appropriacy statistics for passive voice

\begin{tabular}{|l|l|l|l|l|}
\hline \multicolumn{5}{|c|}{ Appropriacy: Passive voice } \\
\hline & Mean & Min & Max & SD \\
\hline Treatment & $96.87 \%$ & $85.71 \%$ & $100 \%$ & $5.174 \%$ \\
\hline Control & $94.68 \%$ & $0 \%$ & $100 \%$ & $16.46 \%$ \\
\hline
\end{tabular}

Reduced relative clauses. Results from a Mann-Whitney U test show the number of appropriate uses of reduced relative clauses was not statistically significant $(\mathrm{p}=0.642)$. The treatment group had a mean of $93.75 \%$ (SD=25\%) for instances of reduced relative clauses which were appropriate while the control group had a mean of $97.93 \%$ (SD=11.14\%). Students in the treatment and control groups were both very successful in using reduced relative clauses appropriately. Only two students choosing to form this structure used it inappropriately. One student in the treatment group formed a reduced relative clause once in their paper, but it was inappropriately used. One student in the control group formed four reduced relative clauses, but three of them were inappropriate. All other students in the treatment and control groups were 100\% appropriate when forming reduced relative clauses.

Table 4.14: Appropriacy statistics for reduced relative clause

\begin{tabular}{|l|l|l|l|l|}
\hline \multicolumn{5}{|c|}{ Appropriacy: Reduced relative clause } \\
\hline & Mean & Min & Max & SD \\
\hline Treatment & $93.75 \%$ & $0 \%$ & $100 \%$ & $25 \%$ \\
\hline Control & $97.93 \%$ & $40 \%$ & $100 \%$ & $11.14 \%$ \\
\hline
\end{tabular}

Modal Would. Data for the number of instances of inappropriate modal would use were non-parametric and a Mann-Whitney U test showed that the 
differences between the two groups were not statistically significant $(p=0.540)$. The treatment group had a mean of $95.19 \%(S D=14.01 \%)$ for appropriate instances of modal would while the control group had a mean of $82.63 \%$ (SD=32.77\%). The maximum for the treatment group was $100 \%$; the minimum was $50 \%$. For the control group, the maximum was $100 \%$, and the minimum was $0 \%$. Use of modal would in treatment and control group papers was inappropriate in only five papers. Two students from the treatment group had an appropriacy error with modal would. One student used modal would eight times, but once it was inappropriately used. Another student from the treatment group did not use modal would but formed one sentence in which modal would was obligatory. In the control group, one student formed modal would twice, but one of those times its usage was appropriate. Another student in the control group formed modal would three times, but two of those uses were inappropriate. All other uses of modal would in treatment and control group papers were appropriate. Appropriacy errors between the two groups in regard to modal would reveal no difference.

Table 4.15: Accuracy statistics for modal would

\begin{tabular}{|l|l|l|l|l|}
\hline \multicolumn{7}{|c|}{ Appropriacy: Modal would } \\
\hline & Mean & Min & Max & SD \\
\hline Treatment & $95.19 \%$ & $50 \%$ & $100 \%$ & $14.01 \%$ \\
\hline Control & $82.63 \%$ & $0 \%$ & $100 \%$ & $32.77 \%$ \\
\hline
\end{tabular}




\section{Chapter 5: Discussion}

While these results did not show statistically significant differences between the two groups, there were differences between the groups' means. Students in the treatment group used passive voice, reduced relative clauses, and modal would more frequently on average than those in the control group. Treatment group students used passive voice a mean of 9.22 times compared to a mean of 8.13 for the control group. Compared with passive voice, reduced relative clauses were not attempted often. Also compared to passive voice, modal would was not frequently attempted.

Both treatment group students and control group students were consistently accurate with their use of passive voice and reduced relative clauses. It is also worth noting that no appropriacy errors related to the criterion "information is not firmly established, highly typical, and widely generalizable" were found in the control or treatment groups. For modal would, there was a slight difference in accuracy: treatment group students correctly formed the feature $97.2 \%$ of the time while the control group only did so $77.4 \%$ of the time. The category for ungrammatical use of modal would due to an incorrectly formed main verb after the modal was not present in the control or treatment group data.

Students in the treatment group and control groups almost always used passive voice appropriately. For passive voice, treatment group students had a mean of $96.8 \%$ appropriacy and control group students had a mean of $94.6 \%$. Students in the treatment group and control group were also similar in their successful use of 
reduced relative clauses: treatment group students had a mean of $93.75 \%$ accuracy and control group students had a mean of $97.93 \%$. For modal would, there was a larger difference: treatment group students had a mean of $95.1 \%$ appropriacy, while control group students had $82.6 \%$.

Two factors should be considered in regard to the data analyzed: sample size and essay topic. There were 25 essay analyzed for the treatment group; a larger collection of essays for this corpus would be more representative of the effect extended instruction may or may not have on ELLs' use of these features. The essay topics for the data may have also contributed to these results. The topics of the essays used in the data collected may have affected the frequency and appropriacy of these particular features. The three topics were "making a change (social justice)," "racism," and "cheating." The necessity of use for passive voice, reduced relative clauses, and modal would should be considered for each essay topic. For example, some topics may affect the frequency and appropriacy of modal would in hypotheticals.

\section{Limitations}

Essay topic distribution. Treatment group student papers were on the topic of "cheating"' or "racism" and control group student papers addressed the topics of "cheating," "racism," or "making a change (social justice)." However, the treatment group did not address the making a change (social justice) topic ( 0 essays on making a change, 20 essays on cheating, 5 essays on racism), while the majority of control group essays were written on this topic (27 essays addressed this topic, 14 on 
cheating, 3 on racism). If the essay topics were more evenly distributed between the two groups, the results may have been more clearly representative of the effect the treatment instruction had. For example, the frequency of passive voice between the control and treatment group was not statistically significant $(p=0.098)$ but may have been closer to significance if the topics were more evenly distributed.

Instructor feedback. The types of comments given to the students on their draft are unknown. As these were the final drafts, it can be assumed that revisions were made by students at least once to attend to grammatical accuracy and appropriacy. If students were given corrective grammar usage feedback from teachers in regard to the features in question, it is possible this affects conclusions about whether students in the control group were less successful than the control group students with accuracy and appropriacy of the features studied. While it can be assumed that both groups of students received corrective feedback from teachers on grammatical features when features were not used accurately or appropriately, it is possible that students in the treatment group received fewer corrective marks in regard to passive voice, reduced relative clauses, and modal would than students in the control group. If this were the case, that difference would not appear in the data analyzed for this study.

Other feedback. It is unknown which papers were influenced by outside help, such as a trained tutor or more advanced writer. While students from both groups may have sought outside help for their papers, help from an outside party raises similar concerns not only to the issue of teacher feedback on drafts, but 
includes the possibility of corrective feedback on final drafts and rephrasing of certain features, such as passive voice, which could also affect data regarding frequency of feature use. An expert user of English or a tutor may be more apt to restructure sentences to include features than a teacher. A trained tutor may see a lack of a feature, such as passive voice, and use the appointment as an opportunity to teach the student about the structure's form and use, then encouraging the student to re-write sentences to include this or other features. In this way, other feedback may influence frequency of features as well. In addition, there are writing style guides from scientific journals which recommend writers avoid use of passive voice (e.g. Journal of the European Medical Writers Association, 2007; Nature, 2011) and even software such as Microsoft Word, programed with these style guides in mind, may direct students to revise a passive sentence they have typed. These could influence student use of passive voice, too.

Avoidance. Another limitation to this study is the possibility of student avoidance regarding the use of these feature. There was no definition and therefore no tagging for instances of when a feature was avoided. This could be an important next step for future researchers to examine in the data. Defining when a feature is not used, but is preferred in academic writing, would then allow for a researcher to see if the ELLs' infrequent use of features, or choice of active over passive voice, is a sign of avoidance of these features. It is possible that the ELLs in this study did not feel comfortable using these structures in their writing, leading them to choose 
structures with which they feel they can more confidently use accurately and/or appropriately.

\section{Future Research}

Reduced relative clauses and modal would. Future research may investigate student use of reduced relative clauses and modal would. The students in this study did not use these structures very often, although they were quite successful at forming them correctly and using them appropriately. Focused instruction on identifying these structures in academic writing and deducing how and why they may be chosen by the author may yield positive results. It may also be of interest to investigate how a production task followed by students editing their own work to include these structures may affect frequency of usage in a separate production task. This approach is different from the guided production tasks used in this study in which students were required to use a certain number of passive sentences, reduced relative clauses, or a certain number of each type of conditional (which included modal would). The difference between these approaches may affect how frequently students use these structures.

Use of -ing forms. The data used for this study could also be used in further research to investigate the use of -ing in these students' papers. Extended instruction for reduced relative clauses was often paired with practice identifying gerunds, reduced relative clauses, reduced adverb clauses, adjectives (before a noun), and regular progressive verbs and producing gerunds and reduced adverb clauses along with producing reduced relative clauses. Looking into the use of 
gerunds—frequency, accuracy, and appropriacy—may be of interest to future researchers several reasons. The treatment group received similar extended instruction on this feature. Also, this feature is frequently found in academic writing, but can be difficult for ELLs to master. Investigating different ways to teach students about gerunds to try and improve the frequency, accuracy, and appropriacy of this structure would benefit many university-bound ELLs.

Essay topics and feedback. A study with more evenly distributed topics, with topics which warrant use of a particular grammar structure, may also lead to interesting results. Considering and controlling the essay topic combined with collecting data before revision by students, teachers, and/or other expert users of English would further confirm if extended instruction in this manner, with these features, has no effect on ELLs' frequency, accuracy, and/or appropriacy.

\section{Conclusion}

It is clear there are many components to a strong academic voice in writing. These components may be difficult for many university-bound students to acquire. For ELLs, a familiarly with conversational, communicative English can present additional challenges some native speakers may not face. Many challenging grammatical structures which are not common in conversation are frequently used in academic writing. As Russell (2014) found, ELLs in PSU's IELP had more difficulties using passive voice, perfect aspect, modal would, reduced relative clauses, and it-clefting. Russell hypothesized that extended and focused instruction 
on these features might lead to better success with these features for ELLs in this population.

This study investigated whether extended time learning about and practicing three grammatical structures-passive voice, reduced relative clauses, and modal would - had an effect on the frequency, accuracy, and appropriacy of use of these features in ELLs' writing. An analysis of the features in the treatment group students' papers compared with the control group students' papers had no statistical difference between the groups' frequency, accuracy, and appropriacy of passive voice, reduced relative clauses, or modal would. There were some interesting findings, however. The mean frequency of passive voice for the treatment group students, while not statistically significant, was higher than students from the control group. ELLs from the treatment and control group both used reduced relative clauses infrequently. When reduced relative clauses and modal would were used, ELLs often did demonstrate accuracy of form and appropriacy of use. From these results, the amount of time, practice, and type of practice with these three features from the standard instruction (control group instruction) given at Portland State's University's IELP does lead to students using these features accurately and appropriately in their writing. These findings show that approaches are needed to increase ELLs' frequency of these features. 


\section{References:}

Azar, B. (2007). Grammar-based teaching: A practitioner's perspective. TESL-EJ, 11, $1-12$.

Balcom, P., \& Lee, S. (2009). The effect of extensive instruction on learning the passive voice in intermediate ESL. ITL, 15, 45-74.

Biber, D. (1988). Variation across speech and writing. Cambridge: Cambridge University Press.

Biber, D., Conrad, S., \& Leech, G. (2002). Longman student grammar of spoken and written English. Essex: Pearson Education Limited.

Biber, D., Gray, B, \& Poonpon, K. (2011). Should we use characteristics of conversation to measure grammatical complexity in L2 writing development?. TESOL Quarterly, 45, 5-35.

Connor, U. (2005). Comment by Ulla Connor. Journal of Second Language Writing, 132-136.

Ellis, R. (2006). Researching the effects of form-focused instruction on SLA. AILA Review, 19, 18-41.

Friginal, E., Li, M., \& Weigle, S. (2014). Revisiting multiple profiles of learner compositions: A comparison of highly rated NS and NNS essays. Journal of Second Language Writing, 1-16.

Hinkel, E. (2002a). Why English passive is difficult to teach (and learn). In E. Hinkel \& S. Fotos (Eds.) New perspectives on grammar teaching in second language classrooms. (pp. 233-258). Mahwah: Lawrence Erlbaum Associates.

Hinkel, E. (2002b). Second Language Writers' text: Linguistic and rhetorical features. Mahwah, NJ: Lawrence Erlbaum Associates, Inc.

Hinkel, E. (2004). Tense, aspect and the passive voice in L1 and L2 academic texts. Language Teaching Research, 8, 5-29.

IIE Releases Open Doors 2015 Data. (2015, November 16). Retrieved June 13, 2016, from http://www.iie.org/Who-We-Are/News-and-Events/PressCenter/Press-Releases/2015/2015-11-16-Open-Doors-Data\#.V2BhhrsrK70 
Hyland, K. \& Milton, J. (1997). Qualification and certainty in L1 and L2 students' writing. Journal of Second Language Writing, 6, 183-205.

Jarvis, S., Grant, L., Bikowski, D., \& Ferris, D. (2003). Exploring multiple profiles of highly rated learner compositions. Journal of Second Language Writing, pp. 377-403.

Jordan, R. (2009). English for academic purposes: A guide and resource book for teachers (10 $10^{\text {th }}$ ed.). Cambridge: Cambridge University Press.

Larsen-Freeman, D., Kuehn, T., \& Hacclus, M. (2002). Helping students make appropriate English verb tense-aspect choices. TESOL Journal, 11, 3-9.

Master, P. (2002) Relative clause reduction in technical research articles. In E. Hinkel \& S. Fotos (Eds.) New perspectives on grammar teaching in second language classrooms. (pp. 201-231). Mahwah: Lawrence Erlbaum Associates.

Mitkovska, L., \& Buzarovska, E.. (2012). An alternative analysis of the English getpast participle constructions: Is get all that passive? Journal of English Linguistics, 40(2), 196-215.

Myers, G. (1989). The pragmatics of politeness in scientific articles. Applied Linguistics, 10, 1-35.

Nassaji, H., \& Fotos, S. (2004). Current developments in research on the teaching of grammar. Annual Review of Applied Linguistics, 24, 126-145.

Norris, J. \& Ortega, L (2000). Effectiveness of L2 instruction: A research synthesis and quantitative meta-analysis. Language Learning, 50, 417-528.

Russell, M. (2014). A Comparison of Linguistic Features in the Academic Writing of Advanced English Language Learner and English First Language University Students. (Unpublished master's thesis). Portland State University, Portland, OR.

Skeleton, J. (1988). Comments in academic articles. In P. Grunwell (Ed.), Applied Linguistics in Society (pp. 98-108). London: Centre for Information on Language Teaching and Research.

Swales, J. \& Feak, C., (2012). Academic writing for graduate students: Essential tasks and skills. ( $3^{\text {rd }}$ ed.) Ann Arbor: the University of Michigan. 
Vande Kopple, W. (1998). Relative clauses in spectroscopic article in the physical review, beginnings and 1980. Written Communication. 15, (pp.170-202).

Warchal, K. (2010). Moulding interpersonal relations through conditional clauses: Consensus-building strategies in written academic discourse. Journal for English for Academic Purposes, 9, 140-150.

Williams, J., \& Evans, J. (1998) What kind of focus on which forms. In C. Doughty \& J. Williams (Eds.) Focus on form in classroom second language acquisition (pp.139-155). Cambridge: Cambridge University Press

Zhou, Y-P. (1992). The effect of explicit instruction on the acquisition of English grammatical structures by Chinese learners. In C. James \& P. Garrett (Eds.), Language awareness in the classroom (pp. 254-257). London: Longman. 